\title{
The Strategic Role of Lean Production in SOE's Development
}

\author{
Shili Sun \\ Department of International Business, School of Foreign Languages, Ludong University \\ No.186 Hongqi Middle Road, Zhifu District, Yantai 264025, Shandong Province, China \\ Tel: 86-535-668-5337_E-mail: shilisun333@yahoo.com.cn
}

\begin{abstract}
Lean production, which has revolutionary production management and practice manner, is the third milestone of human industrialization history. Its key point is to eliminate waste in all aspects of a firm's production activities through establishing production system with high agility. It represents the tendency of modern manufacturing industry. It has been credited as the standard production management approach in the $21^{\text {st }}$ century. Lean production, as an advanced production manner, has important realistic meaning for improving manufacturing's production and management level of China at present, and swelling competitive ability of Chinese enterprises. As the current biggest 'Manufacturing Center' in the globe, it's especially crucial for Chinese enterprises to learn the philosophy of lean production and its impetus for their development.
\end{abstract}

Keywords: Lean production, Benefits, Techniques, Strategic role, SOEs

\section{Introduction}

\subsection{The Understanding of lean production}

Lean production is also called lean manufacturing. It is an integrated set of activities designed to achieve high-volume production using minimal inventories of raw materials, work-in-process, and finished goods. Parts arrived at the next workstation "just in time" and are completed and move through the process quickly. Lean is also based on the logic that nothing will be produced until it is needed. Production need is created by actual demand for the product.

From another angle, lean production refers to a business model that emphasizes meeting customer expectation by delivering quality products and services at the least cost when the customer wants them. The Lean Aerospace Initiative has defined "lean thinking" as:

The dynamic, knowledge-driven, and customer-focused process through which all people in a defined enterprise continuously eliminate waste with the goal of creating value

The lean production system contains several important principles as well as a collection of tactical methods for achieving them. Key lean principles include:

1) Let customers pull value through the enterprise by understanding what the customer wants and producing to meet real demand;

2) Pursue perfection by working to continually identify and eliminate non-value added activity (waste) from all processes;

3) Involve employees in continual improvement and problem-solving activities;

4) Implement a rapid plan-do-check-act improvement framework to achieve results fast and to build momentum;

5) Use metrics and rapid performance feedback to improve real-time decision-making and problem-solving; and

6) Approach improvement activities from a whole enterprise or system perspective.

Lean production typically represents a paradigm shift from conventional "batch and queue," functionally-aligned mass production to "one-piece flow," product-aligned pull production. This shift requires highly controlled processes operated in a well maintained, ordered, and clean operational setting that incorporates principles of just-in-time production and employee-involved, system-wide, continual improvement. Table 1 at the end of this paper illustrates how lean approaches differ from traditional production paradigms.

Lean principles are supported by a set of commonly used tactical methods. Common methods in the lean toolbox include 5S, value stream mapping, kaizen rapid improvement event. Pre-production Planning (3P), Total 
Productive Maintenance (TPM), just-in-time, and cellular design. Some lean organizations also rely heavily on Six Sigma, which includes a set of statistical techniques for identifying and reducing process variation. Each of these tactical methods and tools have clearly defined process steps, techniques, and desired outcomes. Most lean tools are implemented in short, focused "bursts" that include a condensed planning and implementation phase. In this context, there is a strong bias toward implementation, as opposed to prolonged planning. This fits within the continual improvement philosophy that emphasizes making changes to address problems and eliminate waste, tracking performance, and making additional changes to further increase performance.

Lean implementation is typically backed by very strong business drivers. Most organizations pursue lean in response to their need to fundamentally improve business competitiveness by reducing costs, while increasing quality and responsiveness to customer needs (e.g., delivery time). These business competitiveness needs can manifest through increase in direct global competition or from evolving customer or supply chain expectations. Lean practitioners often acknowledge that successful lean implementation can require a real or perceived business crisis to justify or foster receptiveness to the significant transformation that lean requires to an organization's culture and processes.

\subsection{The history of lean production}

Lean production is not especially new. It derives from the Toyota Production System (TPS) or Just In Time Production (JIT), Henry Ford and other predecessors.

The lineage of Lean production goes back to Eli Whitney and the concept of interchangeable parts. Eli Whitney is most famous as the inventor of the cotton gin. However, the gin was a minor accomplishment compared to his perfection of interchangeable parts. Whitney developed this about 1799 then he took a contract from the U.S. Army for the manufacture of 10,000 muskets at the unbelievably low price of $\$ 13.40$ each.

For the next 100 years manufacturers primarily concerned themselves with individual technologies. During this time our system of engineering drawings developed, modern machine tools were perfected and large-scale processes such as the Bessemer process for making steel held the center of attention. As products moved from one discrete process to the next through the logistics system and within factories, few people concerned themselves with:

What happened between processes?

How multiple processes were arranged within the factory?

How the chain of processes functioned as a system?

How each worker went about a task?

This changed in the late 1890's with the work of early Industrial Engineers.

Frederick W. Taylor began to look at individual workers and work methods. The result was Time Study and standardized work. He called his ideas Scientific Management.

Frank Gilbreth added Motion Study and invented Process Charting. Process charts focused attention on all work elements including those non-value added elements, which normally occur between the "official" elements.

Lillian Gilbreth brought psychology into the mix by studying the motivations of workers and how attitudes affected the outcome of a process. These were the people who originated the idea of "eliminating waste", a key tenet of JIT and Lean production.

And then, there was Henry Ford.

Starting about 1910, Ford and his right-hand-man, Charles E. Sorensen, fashioned the first comprehensive Manufacturing Strategy. They took all the elements of a manufacturing system - people, machines, tooling and products, and arranged them in a continuous system for manufacturing the Model T automobile. Ford was so incredibly successful he quickly became one of the world's richest men and put the world on wheels. Ford is considered by many to be the first practitioner of Just In Time and Lean Manufacturing.

At Toyota Motor Company, Taichii Ohno and Shigeo Shingo began to incorporate Ford production and other techniques into an approach called Toyota Production System or Just In Time. They recognized the central role of inventory. The Toyota people also recognized that the Ford system had contradictions and shortcomings, particularly with respect to employees. With General Douglas Macarthur actively promoting labor unions in the occupation years, Ford's harsh attitudes and demeaning job structures were unworkable in post-war Japan.

Toyota soon discovered that factory workers had far more to contribute than just muscle power. This discovery probably originated in the Quality Circle movement. Ishikawa, Deming, and Juran all made major contributions 
to the quality movement. It culminated in team development and cellular manufacturing.

Another key discovery involved product variety. The Ford system was built around a single, never changing product. It did not cope well with multiple or new products.

Shingo, at Ohno's suggestion, went to work on the setup and changeover problem. Reducing setups to minutes and seconds allowed small batches and an almost continuous flow like the original Ford concept. It introduced a flexibility that Henry Ford thought he did not need.

All of this took place between about 1949 and 1975. To some extent it spread to other Japanese companies. When the productivity and quality gains became evident to the outside world, American executives traveled to Japan to study it.

They brought back, mostly, the superficial aspects like kanban cards and quality circles. Most early attempts to emulate Toyota failed because they were not integrated into a complete system and because few understood the underlying principles.

By the 1980's some American manufacturers, such as Omark Industries, General Electric and Kawasaki (Lincoln, Nebraska) were achieving success. Consultants took up the campaign and acronyms sprouted like weeds: World Class Manufacturing (WCM), Stockless Production, Continuous Flow Manufacturing (CFM), and many other names all referred to systems that were, essentially, Toyota Production. Gradually, a knowledge and experience base developed and success stories became more frequent.

In 1990 James Womack wrote a book called "The Machine That Changed The World". Womack's book was a straightforward account of the history of automobile manufacturing combined with a study of Japanese, American, and European automotive assembly plants. What was new was a phrase-"Lean Manufacturing". Lean Manufacturing caught the imagination of manufacturing people in many countries.

\section{Characteristics of lean production}

Lean production builds three major traits: aggressive efforts to satisfy customers, lean operations throughout the entire delivery system, and tight integration of resource networks.

\subsection{Aggressive customer satisfaction effort}

Once a lean producer earns a customer's business, it wants to keep that customer indefinitely. For example, Toyota collects extensive sets of data about its customers, their buying patterns, and their needs. The company works vigorously to anticipate customers' future needs and to build cars that will meet or exceed these needs as they emerge. The lean producer strives always to delight its customers.

Rather than building standard cars for large markets, the MIT study found that lean producers try to break down markets in smaller, more focused niches. Sharp images of cohesive groups of customers allow the firms to accurately describe those people's needs and to match their products closely to those needs. As a result, these firms have developed valuable reputations for sensitivity to customers, and they have reinforced their market images by providing products faster and with higher quality levels than competitors. Their aggressive sales programs treat customers not as obstacles or objectives to capture but rather as partners in close, ongoing relationships for mutual satisfaction and growth.

\subsection{Lean operations throughout the delivery system}

Lean producers attack the two major components of costs: variable or direct costs and overhead. Drawing heavily on JIT techniques and procedures, these firms focus all of their efforts on producing the outputs that customers want with the minimum possible direct costs for labor, materials, and tools. In this way, lean production builds on the foundation laid down by just-in-time manufacturing.

Lean producer also question the need for any activity that either creates overhead or is unnecessary. Through JIT techniques, they attack overhead costs for shipping, receiving, inspection, and rework. In this process, they recognize the limits of their own expertise and do not try to perform every activity necessary to build a product. For example, Chrysler contracted with outside suppliers to design and manufacture components such as seats and radios that lay outside the limits of its expertise, focusing its internal investments on areas critical to its success. This gave the firm the inputs it needed while trimming overhead required for their production from its cost structure.

As a result, lean production significantly affects the firm's break-even point in two ways: by increasing the contribution margin (the difference between the price that customers pay and the firm's direct costs) and by reducing its overhead costs. The contribution margin grows as the firm charges a higher price to deliver a better 
product faster while it reduces direct costs at the same time. Together, these changes drive the break -even point downward, enhancing the firm's flexibility. It can afford to produce smaller quantities, allowing niche marketing, and it can change outputs more quickly in response to changes in customer demand. Compared with mass producers with lower contribution margins and higher fixed costs, the lean produce seems quite agile, leading some to favor the term agile competitor over lean producer.

\subsection{Tightly integrated network of resource}

Like JIT manufacturers, lean producers find opportunities for improvement outside their own internal transformation processes. The managers of these firms try to coordinate all of the resources that contribute to the design, production, and delivery of products to their customers, both within the firm and outside it. They try to actively mange their networks of suppliers, distributors, shippers, and even customers as external resources. They work hard to integrate these inputs through extensive use of technology (e.g. electronic data interchange, bar coding, and automated identification) and coordinating mechanisms such as simultaneous engineering or concurrent design.

Lean production creates a firm that consumes the minimum possible resources to produce the maximum possible value for customers. This organizationwide effort makes the term somewhat inaccurate since the firm seeks to move beyond a lean production system to develop a lean corporation.

\section{Benefits of lean production}

According to the findings from Craig Giffi, Aleda V. Roth, and Gregory M. Seal in 1990, the first North American students of JIT were also attracted by reports of results at firms that had successfully implemented its principles and concepts. For example, one study evaluated the operations of 21 U.S. suppliers to Japanese-managed electronics and automotive companies in the United States. As compared with non-JIT suppliers, the JIT practitioners had generated:

1) Shorter lead time

The study found that 70 percent of the JIT suppliers had reduced their lead times, as compared to only 30 percent of the non-JIT suppliers, allowing them to respond more quickly to changing customer requirements.

2) Lower defect rates

On average, JIT suppliers had 50 percent lower defect rated than non-JIT suppliers. In addition, non-JIT suppliers had to add extra inspections steps just to guarantee acceptable levels of quality to their customers, further increasing overall costs and lead times.

3) Less raw materials inventory

Over 50 percent of the JIT suppliers had reduced their need for raw material inventories, as compared to only 9 percent of the non-JIT suppliers.

4) Less work-in-process inventory

Of the JIT suppliers, 43 percent had reduced their need for work-in-process stocks, as compared to 9 percent of the non-JIT suppliers.

5) Less finished goods inventory

Also, 29 percent of the JIT suppliers operated with less finished goods inventory, as compared to only 18 percent of the non-JIT suppliers.

6) Flexible work forces

JIT suppliers reported that 67 percent of their workers knew two more jobs and 45 percent knew three or more, as compared to 54 percent and 34 percent, respectively, in non-JIT systems. Companies reported more flexible workers brought benefits like less worker idle time, reduces overhead, fewer layoffs due to demand fluctuations in specific product lines, and increased responsiveness.

Many North American managers found JIT attractive in the early 1980s because it offered a new, fundamentally active framework for the task of operations management to replace the reactive model that they had employed. For the first time, just-in-time manufacturing challenged accepted facts of life that before had seemed eternal and unchanging. JIT leaves no fact of life immune to change.

It treats setups, for example, as variable rather than fixed requirements; managers can reduce the time spent making equipment ready if they will spend the time and effort. Among JIT leaders, Toyota has demonstrated this principle by reducing a setup that took 6 hours in a typical U.S. plant down to about 12 minutes. Such reductions 
in setup times do not require extensive involvement of engineers; they come from active involvement by people who work with equipment daily.

JIT also showed large potential gains from reducing scrap, salvage, and rework. It showed how to work with suppliers who were providing unacceptable quality levels, for example, to significantly improve quality in both inputs and finished products. If the suppliers failed to demonstrate avid interest in helping to implement JIT, it advocated replacing them with more willing competitors.

JIT's proactive stance attracted many managers because it revealed their operations in a different light. They were excited by the opportunities it promised to identify potential improvements that they had previously overlooked.

And there are some additional benefits of JIT manufacturing System:

a. Elimination of unpleasant surprises (e.g., late supplier deliveries, unacceptable quality) within the operations management system

b. Reduction in computer system needs

c. Significant improvements in quality

d. Reduction in customer-related problems

e. Substantial reduction in level of inventory, especially work in process

f. Tightening of system variability

g. Shorter lead times

h. Enhancements in system flexibility

i. Reduction in floor space needs

j. Improvements in communication

$k$. Release of pressure on receiving docks and incoming inspection areas

\section{Techniques of lean production}

While seeking for lean production efficiency and effectiveness, employees should be trained to grasp the tactical tools in the lean process, which can direct everyone's efforts at identifying and eliminating waste in the firm. Specially, the following techniques should be emphasized in the daily operations:

1) Kanban/Pulling scheduling

The Kanban or pull scheduling system can immediately and clearly communicate the demands of the customer to the delivery system. In its simplest meaning, the word Kanban is the Japanese term for a card. It is also a name for a system of control cards that govern material movements. By extension, the name also denotes an overall system for day-to-day production and inventory control. In this section, Kanban refers to a system of control cards.

The Kanban control system relies on visual signals such as control cards, empty squares on the floor or a shelf, or even colored golf balls to control the withdrawal and replenishment of materials and components during processing. Kanbans send urgent signals for workers to initiate specific actions immediately, perhaps beginning production of a certain part or transferring inventory. A certain type of Kanban sends a prespecified signal. In this way, Kanban creates a paperless system by which a later stage of production can order specific materials or components from either internal or external suppliers; cards or other signals replace more traditional paper orders. A Kanban system can reach across organizational boundaries to forge real-time links with both customers and suppliers.

2) Reducing setup times

An effective setup-reduction program should pursue four major objectives:

a. Evolve toward lot sizes of 1 unit.

This requires setups that take no longer than the time to produce a single unit of output. We can support the policy of building to order when setup costs are less than or equal to the time it takes to make one unit of production. Such a system can effectively build what customers want when they want it.

b. Run every part every day

This keeps the schedule level. 
c. Make the first piece right every time

Effective setup reduction must not only reduce the time it takes to change over from one part to another; it should also eliminate any need for testing and adjustment, ensuring that every piece emerges from the process perfect the first time.

\section{d. Keep setup times to 10 minutes}

Ideally, the time it takes to change over equipment should never take more than 10 minutes. Evidence confirms that this ambitious goal is very feasible.

To achieve these four goals, any setup reduction program can draw on several procedures, some familiar and some quite new.

Reducing setups can bring many benefits. Quicker setups increase capital turnover rates, earning a higher return on the firm's investment in equipment by maximizing its productive time. Smaller inventory requirements use plant space more efficiently and reduce nonvalue-adding operations such as stock handling and further enhancing productivity. Also, low inventory requirements minimize losses due to unusable stock after model changes or demand forecast errors. Eliminating setup errors improves both quality and safety. Less complicated setups simplify housekeeping and lower operating expenses, as well.

3) Quality at the source

To achieve the objectives of lean production, a firm must develop new ways to view customers and to identify and solve problems. It can no longer merely catch problems after they occur through inspections. Rather, improvement must focus on the sources of products. The quality of a product is determined at the instant, and no amount of inspection will ever make it any better. Lean manufacturing relies heavily on this concept of quality at the source.

Quality at the source forces every person involved in a transformation process to recognize his or her role as a supplier to one or more internal or external customers. The quality of the outputs of later stages of production depends substantially on the quality of the inputs.

Human input is the key to successful implementation of quality at the source. Human workers must study, identify, analyze, uncover, and correct quality problems in the process. The operations manager, in turn, must support these human activities by providing sufficient training (e.g., in the problem-solving tools) and by implementing technology to help support human contributions.

4) Group technology

Group technology gathers all of the equipment necessary for complete production of a family of similar parts to link all operations in a particular process. Group technology is based on the concept of part families, or groups of similar parts. These similarities could reflect common design features or manufacturing needs. After grouping parts into families that share some important characteristics, the operations managers organizes a work cell for each family that gathers together all of the equipment and facilities needed to build that set of parts. The physical layout arranges facilities in optimum sequence to produce the parts in the family.

Group technology work cells shrink physical distances between operations as compared to functional layouts, so they often sharply reduce lead times. In addition, they smooth the flow of orders, leaving less work in process between work centers or waiting in queues than in functionally organized facilities. Since the operator can often move parts between nearby operations by hand, group technology may eliminate the need for automated material-handling equipment. Also, by building similar parts in a single work cell, this system can produce orders with fewer setups than a functionally organized system, which promotes progress toward the JIT goal of building what customers want in the amounts they want with minimum lead times. As a group technology work cell builds a single set of outputs continuously, workers become intimately familiar with the system's outputs and processes, avoiding the need for expensive relearning and helping them to identify opportunities for improvement. Finally, a work cell can improve quality by providing an opportunity for visual inspection after each operation as the operator moves a part from one machine to the next.

\section{5) Focused factories}

In traditional manufacturing, a large factory produces every one of a firm's products in one location to take advantage of economies of scale. However, large plants are more difficult to manage than smaller facilities. In general, managing more people requires more rigid, bureaucratic methods. Also, a large plant often must produce wide varieties of products to achieve the volume of production it needs to justify its fixed costs. This output variety complicates worker training, and it can spread confusion and increase variance even with fully trained 
employees.

A large auto component plant might try to produce similar parts for both auto manufacturers and the repair and replacement part market. Car manufacturers want low-cost components delivered on time, so they provide suppliers with demand schedules for large orders several weeks in advance. In contrast, small distributors buy replacement parts only to meet their customers' repair needs. These buyers need speedy service on comparatively small orders, and demand is difficult to predict because no one knows how many of a particular part will break.

Despite the functional similarity of the parts, a single factory cannot serve both markets without chaos and frustration. The two markets require the firm to compete on different order winners, order losers, and order qualifiers. To satisfy the first group of customers, the plant would have to run large lots with few schedule variations and relatively high levels of capacity utilization. To satisfy the second group of customers, it would have to respond quickly to changing demand, frequently shifting production from one component to another. This variability would interfere with the system's work t meet the demands of the first group of customers.

To resolve this conflict, the plant's managers might replace the single process with a series of linked, focused factories. A focused factory can meet the needs of a specific target market rather than trying to achieve many, potentially inconsistent objectives with a single system. In other words, a focused factory structures its capabilities to be consistent with one market's order winner, order qualifiers, and order losers.

By focusing attention on a limited set of skills and requirements, focused factories reduce the confusion and variance caused by product variety. They also allow better organization of the transformation process to encourage short, quick movements through the system. A focused factory might organize production into a line flow. This would reduce the space between operations, bringing workers close together so they can talk and interact to share information and ideas for improvements. By assigning workers to specific tasks, a focused factory can justify investments in special-purpose equipment. This may also reduce the variety of skills that employees need, making employee training simpler and less costly. The familiar stream of work also helps workers to remember what they have to do and enhances their opportunities to study the process and identify opportunities for adding more value. Focused factories can also reduce the need for storage space.

\section{6) Kaizen/Continuous improvement}

The Japanese discipline of kaizen unites everyone within the organization from top managers and operations managers to operating workers in pursuit of the goal of ongoing improvement. This concept reinforces the emphasis in just-in-time manufacturing on continuing activity to add value to the transformation process and reduce waste. Together, these principles try to inspire everyone in the company to improve one aspect of the operations management system, major or minor, every day.

At Caterpillar of Peoria, Illinois, for example, employees suggested dispensing soft drinks in cans rather paper cups, since the cups were likely to split and create housekeeping problems and they were more difficult to carry, store, and use on the shop floor. Instead, workers could easily carry cans to their work stations and set them aside until they wanted a drink. The combined effects of even tiny changes result in large overall improvements.

\section{Lean production in SOEs}

\subsection{The strategic role of lean production in SOEs}

The huge benefits of lean production in products researching and developing, manufacturing, data management and customer services have been recognized by the whole world. As many specialists pointed out, the main disparity between Chinese SOEs and other top enterprises in the world does not lie on manufacturing equipment, but the operation management and manufacturing system, and this has been improved by some successful enterprises in the country of China. So lean production is the best option for Chinese SOEs to solve their living and developing problems for the following factors:

1) Lean Production came into being when Japan's economy was weakened after war. At that time, Japan was facing the same situation of lacking capital, less and changeable market demanding as we are facing now.

2) Enterprisers, who recognize that management could generate more benefits with fewer pay, attach increasing importance to manufacturing management and production system. At the present, most of China's SOEs are lagged behind in management. Lean production enables them to improve their managerial system.

3) The implementation of lean production (LP) now has a good basis, because some techniques of LP such as Total Quality Control and Kanban system have been put into practice in the country. But the existing problem is how to use these techniques according to the actual situation of China's SOEs, achieving the goal of eliminating wastes. 
4) As a new manufacturing system, lean production has come to maturity, because there are some Lean Thinkers, who continuously improve the lean production theory with full consideration of China's national situation.

5) Some domestic enterprises have set good examples in the aspect of implementing lean production.

6) With the improvement of marketing economy and China's participance in international trade, the whole market has been greatly improved and has more influence to the enterprises.

\subsection{Suggestions of lean production implementation in SOEs}

The basic terms of lean production is universal, which can be used in any enterprise of any country. But it is nonfeasible to simply add some techniques of LP to the original manufacturing system, and even it may arise chaos in management. Thus, there must be a thorough and sound layout for the transfer of old manufacturing methods to LP system. It will be proved effective, provided that China's national situation and the actual conditions of its enterprises are taken into full consideration. The followings are some suggestions for the implementation of LP in SOEs of China.

1) The SOEs of China must attach more importance to reduce cost and improve the profits. In recent years, many SOEs' profits continuously go down, which arouses diverse points of view, but the direct cause is the high cost. The Toyota Company once put forward two formulas to illustrate how an enterprise could run well. The first one is that price $=$ cost $\&$ profit, according to which an enterprise must collapse. The second is that profit=price-cost, which means that price is determined by the market, and reducing cost is the only way for a company to gain profits. The reducing cost is also the profits gained. Therefore, for the SOEs in harsh situation, lowing cost is a best approach for them to get rid off difficulties during their development.

2) SOEs must properly define values, and adopt a market-driven management system. Once the products are produced, they offer service for the society and also create values. But for manufacturers, it is quite difficult to give a definition to values. Lean Production System holds that the customers should give the accurate definition of values, that is to say, values are the products or services supplied to customers at proper price and in stipulated time period. Many SOEs in China just pay attention to products' novelty and techniques' complexity, but they ignore what the customers really want. These enterprises only consider values from the point of their own, pursuing high effectiveness and large-scale manufacturing. As a result, it seems that the unit cost is reduced, but there are huge stocks, which cannot be sold, causing more waste. Thus, from a long-term point of view, SOEs should adopt a market-driven management system, and define values according to the customers' needs.

3) SOEs should implement people-centered incentive managerial mechanism. People are the main body of any management activity. Managers' enthusiasm and passion is a key factor to the success of management. Lean Production System requires SOEs to shift the traditional products-centered management system to people-centered management system.

\section{Conclusion}

China is still stay in middle stage of industrialization; the country lags behind foreign developed countries on science and technology about 20 years, while the commodity economy level drops behind at least 100 years. China has large population, accounting for nearly $1 / 5$ of the whole world, and natural resource per people is far less than world's average level. Region development is uneven, and comparative differences between provinces or regions are higher than comparative differences of other countries. Inefficient economy growth, huge resources consumption, and the resources consumption per unit GDP increase are decuple developed countries.

In order to realize a long-lasting economic growth, it is a cost-effective way for China enterprises to import advanced production system, obviously, LP system is the most suitable one for them, so the management in SOEs of China should combine production, study and research, strengthen dominance to eliminate the barrier which baffle LP application, establish production benefit evaluation system and standard, achieve the great target of improving the comprehensive economic power of the country.

\section{References}

Craig Giffi, Aleda V. Roth, and Gregory M. Seal. (1990). Competing in World-Class Manufacturing: America's $21^{\text {st }}$ Century Challenge. Homewood, III.: Business One-Irwin, pp. 221-222.

Ernest J. Yanarella, \& William C. Green. (1996). North American Auto Unions in Crisis: Lean Production as Contested Terrain. Published by State of New York Press, Albany.

Freddy Balle and Michael Balle. (2005). The Gold Mine: A Novel of Lean Turnaround. Published by the Lean Enterprise Institute. 
James Womack, Daniel Jones, and Daniel Roos. (1990). The Machine that Changed the World: The story of Lean Production. Harper Perennial: A Division of HarperCollins Publisher.

Javier Santos, Richard A. Wysk and Jose M. Torres. (2006). Improving Production with Lean Thinking. Published by John Wiley \& Sons, Inc.

Jeffrrey K. Liker. (2003). The Toyota Way. McGraw-Hill.

Lean Aerospace Initiative. (2002). Lean Enterprise Value: Insights from MIT's Lean Aerospace Initiative. New York: Palgrave, p. 90-97.

Masaake Imai. (1986). Kaizen: The Key to Japan's Competitive Success. New York: Random House, p. xxix.

Michael L. George. (2002). Lean Six Sigma: Combing Six Sigma Quality with Lean Production Speed. McGraw-Hill.

Robert Chalice. (2007). Improving Healthcare Using Toyota Lean Production Methods: 46 Steps for Improvement ( $2^{\text {nd }}$ Edition). American Society for Quality Press.

Robert W. Hall. (1983). Zero Inventories. Homewood, III: Dow Jones-Irwin, p.13.

Ronald G. Askin and Jeffrey B. Goldberg. (2008). Design and Analysis of Lean Production System. Thomson Learning.

Terry Hill. (1989). Manufacturing Strategy. Harvard Business Review, May. pp.113.

Wickham Skinner. (1974). The Focused Factory. Harvard Business Review, June. pp.121.

Womack, James P., Jones, Daniel T., and Roos, Daniel. (1991). The Machine That Changed the World: The Story of Lean Production, Harper Business, ISBN0-06-097417-6.

Yasuhiro Moden. (1993). Toyota Production System. Industrial Engineering and Management Press.

Table 1. How Craft, Mass Production, and Lean Thinking Compare

\begin{tabular}{|l|l|l|l|}
\hline & Craft Production & Mass Production & Lean Production \\
\hline Focus & Task & Product & Customer \\
\hline Operations & Single items & Batch and queue & $\begin{array}{l}\text { Synchronized flow and } \\
\text { pull }\end{array}$ \\
\hline Overall Aim & Mastery of craft & $\begin{array}{l}\text { Reduce cost and increase } \\
\text { efficiency }\end{array}$ & $\begin{array}{l}\text { Eliminate waste and } \\
\text { add value }\end{array}$ \\
\hline Quality & $\begin{array}{l}\text { Integration (part of the } \\
\text { craft) }\end{array}$ & $\begin{array}{l}\text { Inspection (a second } \\
\text { stage, after production) }\end{array}$ & $\begin{array}{l}\text { Prevention (built in by } \\
\text { design and methods) }\end{array}$ \\
\hline Improvement & $\begin{array}{l}\text { Customization } \\
\text { Master-driven continuous } \\
\text { improvement }\end{array}$ & $\begin{array}{l}\text { Expert-driven periodic } \\
\text { improvement }\end{array}$ & $\begin{array}{l}\text { Flexibility } \\
\text { adaptability } \\
\text { Workforce-driven } \\
\text { improvement }\end{array}$ \\
\hline
\end{tabular}

(Source: The Lean Aerospace Initiative, 2002) 